\title{
PRELUDE
}

\section{An Accountability, Written in the Year 2108}

Carolyn Nordstrom

\begin{abstract}
This 'archaeology of the future' examines how we, as scholars and anthropologists, will be read-and judged-in the time to come. Twenty-second-century theoreticians may well ask (as we today ask of colonial-era scholarship): "Did the scholars in the early twenty-first century see in their analyses new kinds of warfare, unparalleled forms of violence, potentialities yet to be developed?" Through an analysis of events likely to unfold over the course of the next 100 years (from changing power constellations to anthropology's attempt to commit disciplinary suicide), this article affirms an anthropology that takes ontological reflexivity seriously; that no longer accepts outdated heuristics dividing theory from theoretician from Being (production of the world); and that grounds this approach in an accountability recognizing epistemology as dynamic, honest, and emergent.
\end{abstract}

Keywords: accountability, epistemology, power, reflexivity, scholars, theory, violence

\section{An Archaeology of the Future}

Did scholars at the dawn of the twenty-first century recognize that their work not only illuminated the past and shaped the present but also produced the future? Did they see in their analyses the harbingers of new kinds of wars, unprecedented forms of violence, undeveloped potentialities? What outcomes did they purposefully or unintentionally contribute to through the cacophonous poetry of their theories? What responsibilities did they shoulder for the legacies they imparted?

Thus begins An Accountability, written in the year 2108. It stands as an archaeology of the future and a reflexivity that ponders how we, as scholars and anthropologists, will be read—and judged—by future history. ${ }^{1}$ 
For much of the first decade of the fledgling twenty-first century, anthropologists in the United States have been producing academic scholarship while at war. With Iraq, certainly. With each other, undeniably. With themselves, perhaps. With lethal inequalities, hopefully. What intellectual and moral bearings animate the heartbeat of their epistemologies as they ripple across and interact to configure, in however large or small a way, our emergent tomorrows?

\section{An Accountability ${ }^{\odot} 2108$}

\section{A Future of a History}

\section{Overview: 100 Years, from the Past to the Present}

Anthropology committed suicide in the mid-twenty-first century. It was a death both epistemological and ontological.

This came to pass as:

The new millennium saw war become a growth industry, ${ }^{2}$ and post-national twenty-first-century non-state hyper-financial giants-economic and political powerhouses-flourished. These organizations resembled reticulated net formations that maximized cross-border linkages (thus avoiding state-based legal systems) to create massive and largely impenetrable webs of ownership across resource extraction, industrial production, global transport, distribution, banking, and security institutions. ${ }^{3}$ Legal and illegal, state and extra-state were heuristic definitions used by analysts. To these reticula, the distinctions were largely irrelevant, employed only when productive. The state was reduced to another out-competed power regime.

Scholars did not foresee these emergent futures. Universities, grounded in nation-state structures, crumbled.

Twentieth-century anthropology demanded accountability for its discipline's harmful actions in the colonial era. Yet was anthropology at that time aware that it stood in the same relationship to a history of the future? Did anthropologists craft their knowledge knowing that they would be held accountable for both the constructive and destructive impact their work would have in shaping global events to come?

It is not a failure that anthropologists on the cusp of the twenty-second century want to repeat.

As anthropology sought to re-establish its ethical tradition-indeed, itself-at the end of the twenty-first century, two events transpired:

first, the discipline accepted as foundational that 'theory is ontological', that is to say that theory has a being as well as a knowledge. It exists only by virtue of being produced, consumed, performed, and interacted, and therefore it can 
be said to be invested with reflexivity. Thus, as we will conclude, 'theory is theoretician, is'.

second, the idea of anthropology as both account and accountability emergedthe idea that our accounts are not merely voices of the world, but ways of creating the world.

\section{An Account's-Ability}

An example of the vast repercussive inter-linkages of a single act helps illustrate the roiling realities of the twenty-first century we speak of here:

In the first decade of the twenty-first century, a bullet is fired in Iraq.

How did anthropology see this? And how did this act of viewing bring us to the world we occupy a hundred years later?

At that point in time, the discipline provided excellent analyses of 'nation' and its 'isms' (nationalism, reificationalism, racism, perspectivism, etc.), inequalities and power, gender and personhood, complex belief systems, nonstate networks, and the lived realities of violence and peace.

Anthropology wove these together to stand at the leading edge of theories of globalization. It was the most sophisticated among the disciplines at understanding the relationships among the visible and invisible facets of human experience: social, intellectual, experiential, econo-political, emotive, phantasmagorial.

But the field was less successful at seeing linkages throughout global experiences as they move across, and configure, for example:

- the global economic flows foundational to hyper-placed beyond-state powers;

- the ironies that as they wrote against oppressive power hierarchies they worked in academies defined by such inequalities, and that these were nationalisms of the state;

- and that these inequalities were experientially related to those arising in war, and simultaneously in domestic realms.

Emergent tomorrows.

We look back at that time and wonder if scholars saw these deep global connections yet found it difficult to publish their findings in a state-based system given to obscuring the subterranean webs of power that the industrial elite depended on. Or perhaps these questions were 'taught out' of academic cognition-invisibilities crafted so successfully by the power brokers of the time that average intellectuals learned to 'not-see'. Were early twenty-firstcentury researchers sitting in coffee shops across the United States discussing the future repercussions of what and how they wrote and did not write? Did they realize that they defined themselves (and no one else) as the theoreticians, even though they produced literature having little impact on the world by virtue of writing style and publishing venues? Did late-night discussions 
link war, the topics they chose to study, child and labor abuses, and the control of financial empires? Did classroom conversations explore the fact that they would be held liable, not by their own standards of the day, but by emergent future epistemes-ones crafted by the very trajectories that they helped set in motion?

Few formal public presentations dug deeply into the fact that the ontological life of theories was generated in institutions shaped within the confines of state ideologies based on hierarchies of job and representation, individualism as success, limited good, aggressive competition, and theoretical wars. Few publications from the United States exist, for example, asking, as Albanian scholars did in the early 1990s, "How many among us will become human rights violators, will become not merely complicit but pro-active in political oppression when our universities crumble on the front lines of war and we are handed guns?"

\section{Emergent Hyper-Placed Non-State Powers in the Early 2000s}

To situate this discussion, it is important to note the kinds of state and extrastate power regimes that were consolidating at that time. And to show that these were far more sophisticated and complex global entities than any of the multi-national corporations, pan-national religious and identity associations, non-state paramilitary and terrorist groups, non-governmental organizations, and criminal networks then in existence. ${ }^{4}$

Wars yielded immense profits. Everything necessary to outfit and sustain fighters, their governments, and their populations flowed from cosmopolitan centers of production. Vast resources (from laboring bodies through the minerals fueling the industrial centers to the luxury items such as diamonds and kidneys that marked inequalities) poured back from the war zones into industrial centers, usually in peace locales, to pay for these costs. Most of the exchanges were trans-state. A significant percentage were extra-legal.

Those who were the most successful at this were business, military, and government leaders who saw the world as a vast web of exchanges in which the state and state-based laws were of only minor importance.

As the twenty-first century progressed, such people harnessed not only the commodity-resource cycles of profit but the means of moving these. International transport adhered only in the loosest of terms to state law and control. With fluid, constantly changing, and multiple countries of registry, incorporation, ownership, and oversight, shipping was itself sovereign. As businesses manipulated multi-country bases, they transferred people, goods, and monies between physical states with sovereign impunity. Profits from the legal and the extra-legal were difficult to unravel, thus making it possible for businesses to invest unrecorded (extra-legal) monies in ways that invisibly maximized their economic and political power. Extra-legal money flows could rival legal ones. Industries bought their own offshore banks and consolidated financial empires. In the early 2000s, a bank could be bought for as little as $\$ 25,000$, and an island to serve as its sovereign base for perhaps $\$ 1$ million. ${ }^{5}$ 
The manipulation of unrecorded finances, invested strategically in the world's stock markets, businesses, and financial institutions shaped these institutions. These vast interrelated networks-legal, extra-legal, undefined-and not the state, were what such leaders saw. It was here economics, politics, identities, and sovereignty were crafted for many.

\section{In the First Decade of the Twenty-First Century, a Bullet Is Fired in Iraq}

This bullet situates two trajectories illustrating the points being made here.

Trajectory \#1: The bullet was a singular object and event. It was locatable in time and space, thought and emotion. The person it hit was a vital compendium of life-a unique body animated by a vibrant personality and situated amid a living history, an irreplaceable present, and a creative interplay of cultures.

Simultaneously, the bullet was part of a vast set of economic and political transactions. The war zones of the early twenty-first century were not isolated nation-state events but interrelated processes spanning the globe that far surpassed the reach of wars. Such 'trans-actions' were defined by movement, not set valuation. They constituted fluidity, and economic empires were created not only within but as flux. Power, said at the time to be 'located', was in fact honed in this hyper-placed flux.

The multi-state economic transactions (from military expenditures through defense contractors to development systems) in which the bullet took 'life' ran in the trillions of dollars. Yearly.

Arms industries, generally situated in peacetime centers, were linked to others that provided life's necessities: food, medicine, communications, transport, energy, hope, and aid. In embattled zones where transport and industry were the first casualties of violence, everyone still had to eat. Had to buy antibiotics. Had to sell themselves for the money to obtain these necessities. Sometimes these links were associative, for example, arms businesses partnering with energy and transport ones. Other times, diverse goods and services were all part of a single transnational corporation-one that could broker oil deals, supply the weapons to the militaries presiding over the deposits, and provide life's necessities to workers and troops alike. Determining where a state began and ended in these transactions-much less its complicity in extra-legal actions and the exploitation of desperate labor-was formidable at best, if not impossible.

War and reconstruction had to be purchased. The payment exacted by peacetime locales (the valuable raw resources fueling global cosmopolitan politico-market hegemony) gutted the countries at war of the very means to reconstruct.

Unaccountability was strategic.

A difficulty in untangling all this was that both a racketeer in forced child prostitution and the 1991 Nobel Peace Prize Laureate Daw Aung San Suu Kyi, who stood against oppressive rule in Myanmar, were painted with the label 'criminal' in formal legal terms. 
A contradiction was thus embedded in the very core of the state. Great fortunes and great cruelty thrive in the realm of the unregulated. But ironically, the realm of the unregulated was also where the average person turned for survival in an unsure world. It was here that ordinary citizens could gain the currency to buy industrial necessities, agricultural supplies, and development goods. Such (illicit) goods purchased hard currency, helped broker power, and allowed investments in land, legal industries, and political partnerships for the disenfranchised and desperate. These spawned and supported subsidiary industries, both legal and illicit. Daily necessities followed these same development trajectories. When government frameworks are in flux, non-state networks are often the only support and supply systems functioning.

It is in this vast extra-legal domain that power regimes are contested, where new forms of capital, access, and authority arise, some crumbling before they master any real influence in global affairs, others supplanting old regimes with new. It is this very paradox - the extra-state abusively wild-catting outside legal controls, yet affording development for people with few means of survivalthat made the extra-legal such a powerful force of change in the 2000s.

What responsibility did US scholars at this time, as citizens in a country at war, take for addressing such phenomena as represented in the following examples:

extra-legal profits were invisibly laundered into political power and had an impact in shaping emergent national economies.

A weapon sold is a sale, whether it is legal or not. Perhaps the unrecorded sales were more attractive, especially for legal national and multi-national businesses. Laundering untracked monies into legal economies (through legitimate businesses, stocks and bonds, and financial institutions) could offer significant control of those markets. The elite of the extra-legal controlled more money than the gross national product (GNP) of many of the world's countries. This could be called a twenty-first-century form of global warlordism, much of it rooted in peacetime cosmopolitan-center businesses.

uncharted economies were beyond law, beyond accounting.

The key question, of course, is why these extra-legal economies were not recorded. It is hard to fathom how economic indices based solely on formally recorded monies and economies were accepted universally when massive flows of extra-legal commodities, services, and monies were fundamental in defining political processes and economic health worldwide. Gross domestic product (GDP) calculations were in actuality far from being 'gross' in that they considered only the legal. No economic indices for calculating a GDELP (gross domestic extra-legal product) existed. Simply put, there was no way, for example, to find data on the entire extra-legal profit in Europe in 2010, or how laundering it into the legal economy affected stock, interest, and currency rates.

The answer rests in the fact that those seeking to control vast financial empires eschewed transparency. Virtually all of the trillions of dollars that moved across 
the boundaries of legality ultimately passed through formal (legal) economies in ways that proffered forceful zones of profit and power. The excesses and abuses of war were linked to global systems of exchange that were deeply woven into the fabric of everyday life and formal institutions.

severe financial collapses resulting from global-level profiteering destroyed entire economies by the mid-twenty-first century, fanning the flames of war and repression yet again.

These were foreseeable events based on historical precedents, the most obvious being the collapse of the colonial world, the cycles of economic depressions and failed states, and, centuries earlier, the disintegration of kingdoms and regional empires against the ascending supremacy of the Enlightenment state. Merchants in the Middle Ages developed international commerce systems intended to stand apart from kingly rule. These actions, extra-legal to monarchic law, were often deemed criminal. They presaged the development of the state just as the extra-state networks of modernity later foreshadowed poststate politics. Power by definition is not a teleological process.

states eroded under the weight of emergent forms of economic and political suzerainty;

and what academics 'saw'-what they made visible and invisible in theoryhelped set these realities into motion.

We now know to ask: if analysts cannot see the full compendium of economic, political, and social forces defining the evolving twenty-first century, yet those controlling the intersections of the extra-legal and legal across war and peace can, who defines power?

It seems self-evident that those forging suzerainty both inside and outside the state and its laws knew that economics at that time was a pas de deux of the il/legal. They were aware that these constructions heralded new post-state powerhouses partaking of state institutions when convenient and forging non-state ones when necessary. But publications by many of the economic and political analysts of those days demonstrated that an understanding of these complex extra-state realities all too often faded into incomprehensibility. Removed from global understanding, isolated tales of warlords, terror, crime, and corruption were shot through with myths and assumptions.

The explanation for this may rest with the fact that from the Enlightenment to the early twenty-first century the sciences took shape and structure within the confines of the state. Research knowledge was begot in the womb of the state and delivered by the midwife of modernity. Academics came of age embedded in state institutions, and thus they privileged it. 'State' is a conceptual category, not an objective entity. It exists only because people believe in the laws, geographical designations, and imagined communities that designate the flow and flux of humanity and space into discrete parts. It is an abstract 
notion given substance by virtue of being recognized as substantive. A state needs academics to theorize it into being. Academics need institutions to recognize them and financially support them to bring them into being.

From a state-centered perspective, anything outside the state is seen as less substantive, less powerful, less dynamic. And is less studied. Unable to 'see' (in theory, data, analyses, and policy) non-state actualities, state-based institutions were blind-sided by these actualities.

Reality was the weapon that toppled state supremacy.

Trajectory \#2: As the bullet was fired in Iraq, other forms of violence simultaneously increased. The bullet, although unique, was also embedded in a vast generalized pattern of violent societal acts:

the rise in political violence correlated with a rise in domestic, gender, sexual, and criminal violence.

Crises were embedded in crises. Profits were layered in profits. Abusive practices were hidden in proclaimed social values. Intertwined, overlapping, and interpenetrating contexts rippled across the world's continents.

When the pathologically abusive-that which violates human rights and endangers lives-was inculcated into social systems, the values attaching to it came to have a far broader impact. The lines of il/legality were strongly blurred for populations in general: average businesses used undocumented labor and offshore accounts; average citizens more frequently raped (or battered or killed) or were raped (battered, killed); average 'patriots' turned to illegal profiteering.

wars' end did not signal an end to these higher levels of violence.

Statistics worldwide suggested that at the turn of the twenty-first century roughly one-third of the global population experienced domestic/interpersonal violence, although individual countries varied from far less to more than twothirds of the population. People then were just beginning to explore the correlation: if trauma from political violence impairs societal recovery, trauma from any violence will have the same effect. Popular culture had long offered the image of military leaders presiding over a desolate pile of rubble-the kingdom that they had decimated in order to wrest control of it. But another reality was less easily captured by the popular imagination or academic investigation: the political leader presiding over a broken and maimed society, a shattered cultural stability, a wounded daily reality. ${ }^{6}$

linkages among differing forms of violence extended across both time and space.

For example, by the advent of the twenty-first century, a large percentage of prison populations in the United States had suffered from domestic, sexual, and/or interpersonal violence growing up. Crime in post-war conditions did not fall, and in a number of cases it increased. ${ }^{7}$ 
Several interconnected factors brought about this rise: devastated post-war economies remained unable to provide the essentials for populations; war profiteers shifted not to legal pursuits but to new lucrative ventures; unscrupulous military and political actors sought to maximize their power through corrupt earnings. As the Mozambicans explained at the time, people had learned violence but failed to unlearn it. Violence had become an institutionalized habit across the terrains of crime, security, business, and home. ${ }^{8}$

while all of these realities were evident to twenty-first-century anthropology, it tended to characterize correlations between contemporary war, long-term domestic and civil violence, complex extra-state networks, and the temporary demise of the field 50 years later as problematic at best, ridiculous at worst.

\section{Epistemological Suicide?}

In the subsequent 100 years, an epistemic change has taken place that renders it impossible not to see the ways in which these various trajectories unfold and define one another within larger universes of human meaning and interaction. In watching the nation-state unravel and collapse, theoreticians have been able to discern how emergent forms of power politics and its related economies come into being. It is said colloquially that the ashes cannot recognize the phoenix rising from them.

While these futures were not woven into the theoretical todays of the early 2000s, it is important to recognize that anthropology at that time helped set the stage for the deeply reflexive definition of ontological theory that emerged. It pushed the limits of these inquires further than any other field with the exception of theoretical physics. At the same time, anthropology struggled within a larger pan-state epistemological system that failed to recognize that as we create knowledge, we create our nascent selves. We now conclude: given that epistemology is knowledge, it appears that anthropology did not recognize itself.

If the scholars in the first decade of the twenty-first century had created theories fully engaged with the truths of their world and their place in it-past, present, and future-would this century have suffered such severe repressions, economic collapses, power abuses, and social crises?

We now wonder: did anthropology commit suicide?

\section{Ontological Reflexivity}

Time corrects.

Anthropology was not dead. It reanimated itself with the idea that not only people but also the theories they 'live' can be considered reflexive. Theory ceased to be seen as a product or a performance enacted by the academic 'ego as I'. It became imbued with the same complex of interactions-cognitive, existential, 
phenomenological, emotive-that define theoreticians, that is, humankind, and their productions within the larger world.

Today we know that the theories we create and employ are generative. The Cartesian dichotomy between producer and product, between subject(ivity) and object(ivity) has been laid largely to rest: 'theory is theoretician, is'.

The way we explain our todays creates our tomorrows. We are as accountable for what we choose not to see and address as we are for what we do. We are as responsible for the existential and emotive content of our epistemologies as we are for the cognitive. Any notion of 'theoretical' and 'applied' today seems barbaric, a way of perpetuating meaningless yet divisive large-scale (intercontinental) political agendas. We expect anyone writing on power and inequality to explore the ways that working in a university or organizational system based on hierarchies of inequality (tenure systems, grant and publishing gate-keeping, zero-sum competition, theoretical wars, etc.) shapes their epistemologies.

Writing An Accountability today also embraces the recognition that we can read the interrelated trajectories of our world. Theory oftentimes is habitus-a straightjacket into which we confine ourselves. Accountability, like reflexivity, carries the premise that we can know more than we know. Epistemology is vibrant, unfolding, emergent.

Rather than trying to see theory as a dispassionate way of looking out on the world in an attempt to explain it, theory is now seen as part of life's engagement in the world. Theory-produced, performed, enacted, engaged-is intrinsic to being, and to being human.

Recognizing this, we must then ask in our theoretical work: how do we want to be human?

\section{Postscript from 2008}

Where have these rules of what and how we research and write come from? How do we confer power on our gatekeepers? And why in our academic lives do we follow the patterns of power that our work decries? Those who benefit from war zone violence seek to silence social scientists who have the courage to speak to the future of power. Those who benefit from global war today seek the same silencing. And social science seems to have obliged by producing theories that-due to writing style, publication venues, jargon, arrogance, fear, and uncontested rulesextend little beyond the narrow confines of the subdisciplines of the field.

Will this be judged in the future as complicity with dangerous forms of hegemonic power?

Will the poor starving peasant woman who finally fights back against an abusive solider or the actively oppressed artists who take their critiques to the streets to educate or the children who ask for and expect engaged scholarship from their teachers be seen by future generations as more courageous-both intellectually and personally - than today's 'cutting-edge academics'? 


\section{Notes}

1. This discussion points to North American scholars because it is my academic home and because I do not think it is appropriate to critique those of other countries. However, this is not meant to imply a North American-centric perspective. On the contrary, the article is concerned with that which ripples across the terrains of space and time.

2. Most analysts considered only the visible. For example, the top ten global defense contractors (curiously calculated without considering countries like China) in 2006 alone made $\$ 200$ billion in defense revenue and $\$ 415$ billion in total revenue (http:// www.defensenews.com/index.php?S $=07$ top100byrevenue). Only 26 countries that year had gross domestic products over that sum (http://www.imf.org/external/pubs/ft/ weo/2007/01/data/index.aspx). Further hundreds of billions were made yearly in extralegal arms sales (see Nordstrom 2004).

3. See Naím (2006), Naylor (2005), and Nordstrom (2007).

4. The formation of these hyper-placed non-state powers followed a trajectory similar to that of the 1600s, when the phoenix of the newly born state rose from the ashes of kingdoms and regional empires. By the 2000s, it was the state that was the old man of politics. The familiarity of the process should have been more apparent to those conducting analyses.

5. See Naylor (2005).

6. See Das (2006), Das et al. (2000), Kaldor (2007), and Zizek (2006).

7. See Darby (2005) and Nordstrom (2004).

8. See Nordstrom (1997).

\section{References}

Darby, John. 2005. Violence and Reconstruction. Notre Dame, IN: University of Notre Dame Press.

Das, Veena. 2006. Life and Words: Violence and the Descent into the Ordinary. Berkeley: University of California Press.

Das, Veena, Arthur Kleinman, Mamphela Ramphele, and Pamela Reynolds, eds. 2000. Violence and Subjectivity. Berkeley: University of California Press.

Kaldor, Mary. 2007. New and Old Wars: Organized Violence in a Global Era. Palo Alto, CA: Stanford University Press.

Naím, Moises. 2006. Illicit: How Smugglers, Traffickers, and Copycats Are Hijacking the Global Economy. New York: Anchor Books.

Naylor, R. T. 2005. Wages of Crime: Black Markets, Illegal Finance, and the Underworld Economy. Ithaca, NY: Cornell University Press.

Nordstrom, Carolyn. 1997. A Different Kind of War Story. Philadelphia: University of Pennsylvania Press.

2004. Shadows of War: Violence, Power, and International Profiteering in the TwentyFirst Century. Berkeley: University of California Press.

2007. Global Outlaws: Crime, Money and Power in the Contemporary World. Berkeley:

University of California Press.

Zizek, Slavoj. 2006. The Parallax View. Cambridge, MA: MIT Press. 